\title{
Cancer prevention - is it a Realistic Notion?
}

\author{
Karel Petrak* \\ Nangio Tx Incorporated, USA
}

Submission: February 07, 2018; Published: February 26, 2018

"Correspondence Address: Karel Petrak, Nangio Tx Incorporated, 555 Fifth Avenue, New York, NY, USA, Email: klpetrak@gmail.com

Abstract

Many potential causes of cancer have been identified, and many attempts have been made to inhibit cancer initiation and progression. It is argued here that cancer prevention will not be possible until unique and primary mechanism(s) that direct cells to undertake cancerous division are identified, and until the ways of inhibiting such mechanisms are found. It has been suggested many years ago that cancer is a preventable disease [1]. PubMed search for "cancer and prevention", performed on 5 February, 2018, gave 202,297 publications, indicating that a substantial research efforts are being made in this area. How realistic is cancer prevention?

\section{Commentary}

Many potential causes of cancer have been identified [2]. The authors examined several potentially modifiable risk factors, concluding that smoking and alcohol use were the most frequent causes of cancer across the world, in both high- and low-middleincome countries. Persistent infections with human papilloma virus (HPV) have been found to be a major risk factor for women. However, not all cancers such as prostate, kidney, melanoma, and lymphomas were found not to be associated with any modifiable risk factors, largely because multiple environmental and behavioral risks might be involved. Further, risks associated with occupational exposures, Helicobacter pylori and components and additives in food, and exposure to ultraviolet light and environmental tobacco smoke need to be considered. However, evaluation of such is difficult because accurate exposure data (e.g., extent of exposure to environmental tobacco smoke, ultraviolet light, protection used, etc.) are no available.

Some argue [3] that "the obsession with curing advanced disease has prevented progress in the war on cancer". Efforts to prevent cancer need to start at a personal level, by avoiding risks that each individual can eliminate, such as by not smoking, limiting exposure to ultraviolet light, maintaining healthy diet and life style, etc. We need to recognize that ability to do so will much depend on individual financial situation.

It is, however, much more important that the society, effectively enabled by governments making the required decisions about policies, implementation, and funding, starts putting measures in place that eliminate, or at least reduce the global presence of cancer-causing behavioral and environmental factors.
Although it is "politically correct" for governments, organizations and environmental groups, and even prominent individuals such as Hollywood film stars and Prince Charles to spend much time in discussions on how to correct the current environmental conditions, very little effective, if any actions have been generated and come to pass. Advice given to general public that comes out from such activities is rather weak: "Go Green and buy products that are environment friendly."; "3Rs Reduce, Re-use and Recycle."; "Plant trees wherever you can" [4].

What are some of the environmental factors that need to be addressed? It is "comfortable" to "blame" global warming, but our task is to ensure that our air, water, the land, and all natural resources (including sources of food such as animals) are free of harmful contaminants. The task is getting increasingly challenging as the size of the human population grows, requiring more land, water, and of everything - cars producing emissions, industrial activities generating toxic waste, more carbon emissions-all adding toxins into our environment. Is it realistic to make behavioral and environmental changes to decrease cancer-causing factors while we extract some 55 billion tons of fossil energy, minerals, metals and bio mass from the Earth? While we continue to reduce forested areas at a rate of $375 \mathrm{~km} 2$ per day? While we have a "garbage island" floating in our ocean the size of India, Europe and Mexico combined? [4].

With all that background, it is unrealistic to expect that all environmental causes of cancer can be eliminated. By all means, we should work towards making and keeping our environment clean, however, cancer prevention will not be realistic until the key, unique and primary mechanism(s) that direct cells to 


\section{Cancer Therapy \& Oncology International Journal}

undertake cancerous division are identified, and the ways of inhibiting such mechanisms are found.

\section{References}

1. Richard Doll, Richard Peto (1981) The Causes of Cancer: Quantitative Estimates of Avoidable Risks of Cancer in the United States Today. JNCI 66(6): 1192-1308.

his work is licensed under Creative
2. Sporn MB (1996) The war on cancer. Lancet 347(9012): 1377-1381.

3. What are the solutions to environmental degradation?

4. Environmental Destruction (2016) World Centric. Commons Attribution 4.0 License

DOI: $10.19080 / C T O I J .2018 .09 .555768$

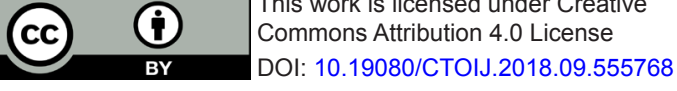

Your next submission with Juniper Publishers will reach you the below assets

- Quality Editorial service

- Swift Peer Review

- Reprints availability

- E-prints Service

- Manuscript Podcast for convenient understanding

- Global attainment for your research

- Manuscript accessibility in different formats

( Pdf, E-pub, Full Text, Audio)

- Unceasing customer service

Track the below URL for one-step submission https://juniperpublishers.com/online-submission.php 